\title{
Influence of the neural tube/notochord complex on MyoD expression and cellular proliferation in chicken embryos
}

H.J. Alves, L.E. Alvares,

J.E. Gabriel and

L.L. Coutinho
Departamento de Produção Animal, Escola Superior de Agricultura "Luiz de Queiroz", Universidade de São Paulo, Piracicaba, SP, Brasil

\section{Correspondence}

L.L. Coutinho

Departamento de Produção Animal

ESALQ, USP

Av. Pádua Dias, 11

13418-900 Piracicaba, SP

Brasil

Fax: +55-19-3429-4285

E-mail: Ilcoutin@carpa.ciagri.usp.br

Research supported by CNPq and

FAPESP. H.J. Alves and L.L. Coutinho

were recipients of $\mathrm{CNPq}$ scholarships.

Received April 18, 2002

Accepted November 7, 2002

\begin{abstract}
Important advances have been made in understanding the genetic processes that control skeletal muscle formation. Studies conducted on quails detected a delay in the myogenic program of animals selected for high growth rates. These studies have led to the hypothesis that a delay in myogenesis would allow somitic cells to proliferate longer and consequently increase the number of embryonic myoblasts. To test this hypothesis, recently segmented somites and part of the unsegmented paraxial mesoderm were separated from the neural tube/ notochord complex in HH12 chicken embryos. In situ hybridization and competitive RT-PCR revealed that $M y o D$ transcripts, which are responsible for myoblast determination, were absent in somites separated from neural tube/notochord (1.06 and $0.0610^{-3}$ attomol MyoD/ 1 attomol $\beta$-actin for control and separated somites, respectively; $\mathrm{P}<0.01)$. However, reapproximation of these structures allowed $M y o D$ to be expressed in somites. Cellular proliferation was analyzed by immunohistochemical detection of incorporated BrdU, a thymidine analogue. A smaller but not significant $(P=0.27)$ number of proliferating cells was observed in somites that had been separated from neural tube/notochord (27 and 18 for control and separated somites, respectively). These results confirm the influence of the axial structures on $M y o D$ activation but do not support the hypothesis that in the absence of $M y o D$ transcripts the cellular proliferation would be maintained for a longer period of time.
\end{abstract}

\section{Introduction}

The number of muscle fibers in an adult animal is the result of a complex series of molecular events that control the commitment of mesodermal cells to become myoblasts and subsequently to differentiate into myofibers (1-3). Skeletal muscles are derived from somitic cells, which initially form
Key words

- Chicken development

- MyoD

- In situ hybridization

- BrdU

- Cellular proliferation
- Myogenesis the epaxial muscles (as the deep back muscles) and later those of the ventrolateral body wall and limbs (2). Several genes responsible for promoting determination and differentiation of muscle cells have been identified (1-3). The first such gene to be cloned was the myogenic factor $M y o D$ (4). Further studies revealed that this gene is member of a family composed of four related 
genes (MyoD, Myf-5, myogenin and MRF4), which are the main regulators of myogenesis in vertebrates (5-7).

The influence of the neural tube/notochord (NT/NC) complex on the myogenic program is controversial, since the experimental approaches that have been applied in these studies are complex and sometimes produce conflicting results $(3,8)$. In spite of this, most studies have agreed on the importance of signals emanating from axial structures (NT and NC) to the activation and/or maintenance of myogenic factor expression (9-11). In the present study, we performed microsurgical separation of recently formed somites from the NT/NC complex in HH12 embryos, attempting to block MyoD expression. Since a delay in activation of myogenic factors was identified during the embryonic development of quails selected for high growth rates (12), we decided to test the hypothesis that the lack of $M y o D$ expression caused by physical separation from axial structures could enable somitic cells to proliferate for a longer period of time and thus produce an enlarged population of myoblasts. If this were the case, the delay in $M y o D$ expression could explain the increase in muscle mass observed in quails.

\section{Material and Methods}

\section{Egg incubation and embryo collection}

Chicken eggs of the Ag Ross lineage from the Ninho Verde poultry farm (Tietê, SP, Brazil) were incubated at $38^{\circ} \mathrm{C}$ for $48 \mathrm{~h}$. Embryos were collected using filter paper disks and staged according to Hamburger and Hamilton (13).

\section{Microsurgery to separate and reapproximate NT/NC somites}

After removal from the egg, $\mathrm{HH} 12$ embryos were submitted to microsurgery using needles to separate the last formed somites and part of the unsegmented paraxial mesoderm from the NT/NC complex. Operated embryos were kept in culture medium $(0.36 \%$ $\mathrm{NaCl}, 1.0 \%$ agar, $50 \%$ fine egg white) at $37^{\circ} \mathrm{C}$ for 12 to $16 \mathrm{~h}$ in a moist atmosphere. For reapproximation, somites were placed in contact with the neural tube by needlepoint and microsurgical thread. These embryos were incubated for an additional $8 \mathrm{~h}$.

\section{In situ hybridization}

In situ hybridization assays were performed as described (14). Embryos were fixed in $4 \%$ paraformaldehyde at $4^{\circ} \mathrm{C}$ for 16 $\mathrm{h}$ and dehydrated in $70 \%$ ethanol. An antisense $M y o D$ probe labeled with digoxigenin was obtained by in vitro transcription as established by Gabriel et al. (15). MyoD transcripts were detected by immunodetection using an anti-digoxigenin antibody conjugated with alkaline phosphatase. A colorimetric reaction was performed to detect signals using the chromogenic substrates NBT and X-phosphate (Genius System Kit, Roche, Indianapolis, IN, USA). The color development reaction was performed for $8 \mathrm{~h}$ and stopped by incubation in TE buffer $(10 \mathrm{mM}$ Tris-HCl, 1 mM EDTA, pH 8.0). Embryos were photographed using a Leica WILD MP8 stereomicroscope and stored in TE at $4^{\circ} \mathrm{C}$.

\section{Detection of cellular proliferation}

Proliferating cells were detected by incubating embryos in $1 \mathrm{X}$ PBS buffer $(0.14 \mathrm{M}$ $\mathrm{NaCl}, 2.7 \mathrm{mM} \mathrm{KCl}, 10 \mathrm{mM} \mathrm{Na}_{2} \mathrm{PO}_{4}, \mathrm{pH}$ 7.4) containing $50 \mu \mathrm{M}$ 5-bromo-2'-deoxy-uridine (BrdU) for $1 \mathrm{~h}$ at $38^{\circ} \mathrm{C}$. Embryos were then prepared for histology using JB4 plastic resin (Polysciences, Warrington, PA, USA). Histological sections of $8 \mu \mathrm{m}$ were placed on glass slides and kept on a heated plate $\left(45^{\circ}\right.$ to $50^{\circ} \mathrm{C}$ ). BrdU was detected using a BrdU labeling and detection kit (Roche), with an antiBrdU antibody (16). Slides were photographed with an inverted microscope (Leica DMIL). 


\section{Competitive RT-PCR}

Three somites were surgically removed from the operated and contralateral (control) sides after 12-16 h of in culture incubation. Immediately after, the extractions of total RNA were performed as described by Chomczynski and Sacchi (17). The full amount of total RNA obtained from the dissected somites was used for cDNA synthesis with the SuperscriptII reverse transcriptase (Life Technologies, Carlsbad, CA, USA). $M y o D$ and $B$-actin transcripts were quantified by competitive RT-PCR as described by Alvares LE, Mantoani A, Corrente JE and Coutinho LL (unpublished data). In brief, 2 $\mu l$ of cDNA were co-amplified with $10^{-3}$ attomol or 1 attomol of competitor fragments for $M y o D$ and $\beta$-actin, respectively. The PCR incubation mixture contained $1 \mathrm{X}$ PCR buffer (10 mM Tris-HCl, pH 8.3, 50 $\mathrm{mM} \mathrm{KCl}, 0.01 \%$ Triton X-100), $1.5 \mathrm{mM}$ $\mathrm{MgCl}_{2}, 5 \mathrm{pM}$ of direct (5'-fluorescein labeled) and reverse primers, $10 \mathrm{mM}$ dNTPs, and $2 \mathrm{U}$ Taq DNA polymerase. The final reaction volume was $25 \mu \mathrm{l}$. For $\beta$-actin, the amplification conditions were: initial denaturation at $95^{\circ} \mathrm{C}$ for $3 \mathrm{~min}$ followed by 25 cycles of $1 \mathrm{~min}$ at $95^{\circ} \mathrm{C}, 1 \mathrm{~min}$ at $55^{\circ} \mathrm{C}$ and 1 min at $74^{\circ} \mathrm{C}$. In the last cycle, a final extension was carried out at $74^{\circ} \mathrm{C}$ for $10 \mathrm{~min}$. Cycling parameters used for $M y o D$ were the same, except for the annealing temperature and number of cycles, which were $57^{\circ} \mathrm{C}$ and 35 , respectively. PCR products were separated and quantified with an automatic sequencer (Automated Laser Fluorescent DNA Sequencer, ALFTM, Pharmacia, Uppsala, Sweden). The content of $M y o D$ and $\beta$-actin transcripts was calculated on the basis of linear equations obtained from standard curves constructed for each gene. B-Actin mRNAs were measured in the same reverse transcription reactions to correct samples for variations in amount of total RNA as well as for reverse transcription efficiency.

\section{Results and Discussion}

\section{$M y o D$ expression in chicken embryos}

Initial experiments were carried out to study the expression of $M y o D$ in whole embryos. Figure 1 shows the spatial distribution of $M y o D$ transcripts in an HH12 chicken embryo. MyoD transcripts were detected (dark stain) in the dorsomedial region of the somites next to the neural tube. Expression was most intense in mature somites, which are located near the cephalic region, and decreased in younger somites, localized close to the caudal extremity of the embryo. These results agree with reports in which $M y o D$ transcripts were detected in serial sections of quail embryos (18) and in whole mount chicken embryos (15).

\section{Influence of NT/NC on MyoD expression}

To determine if we could block $M y o D$ activation in somites, the last formed somites and part of unsegmented paraxial mesoderm

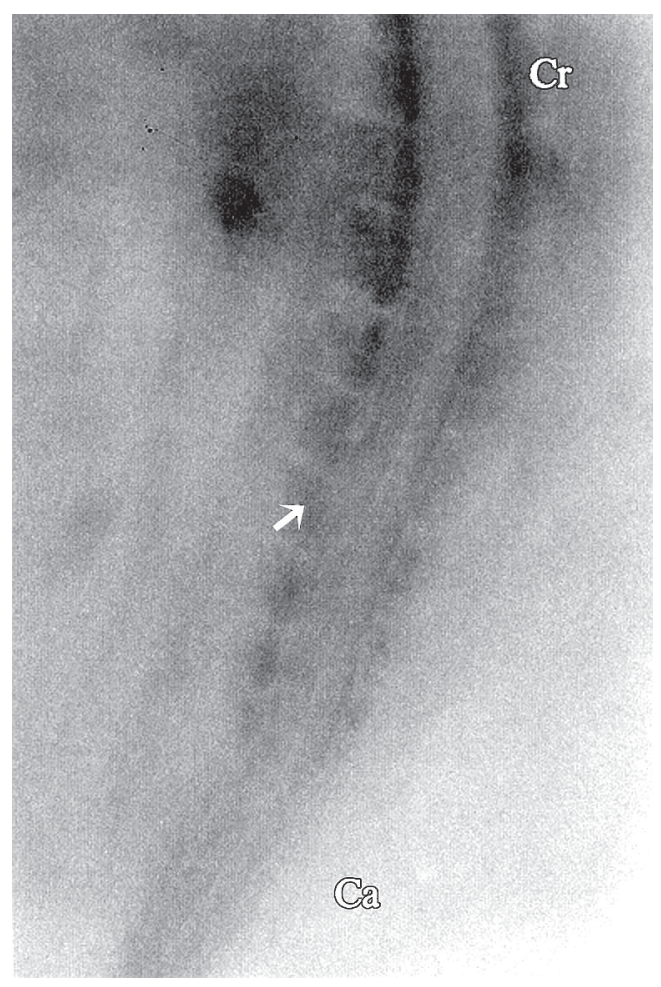

Figure 1. Photomicrograph of an $\mathrm{HH} 12$ chicken embryo. MyoD expression is restricted to somites (arrow). Embryo orientation: $\mathrm{Cr}$ (cranial end), Ca (caudal end). 
Figure 2. Effect of microsurgical separation of somites from the neural tube/notochord (NT/NC) complex on MyoD expression. A, Separation of somites and part of unsegmented paraxial mesoderm of the NT/NC complex in an $\mathrm{HH} 12$ embryo. $B$, Operated embryo 12-16 h after microsurgical manipulation. C, In situ hybridization to detect MyoD transcripts 12-16 $\mathrm{h}$ after surgical manipulation (arrow). D, MyoD expression after reapproximation of somites to the NT/NC (arrow). Embryo orientation: $\mathrm{Cr}$ (cranial end), Ca (caudal end). were separated from the adjacent axial structures as shown in Figure 2A. An operated embryo is presented in Figure 2B, after 12 to $16 \mathrm{~h}$ of in culture incubation at $37^{\circ} \mathrm{C}$. It is
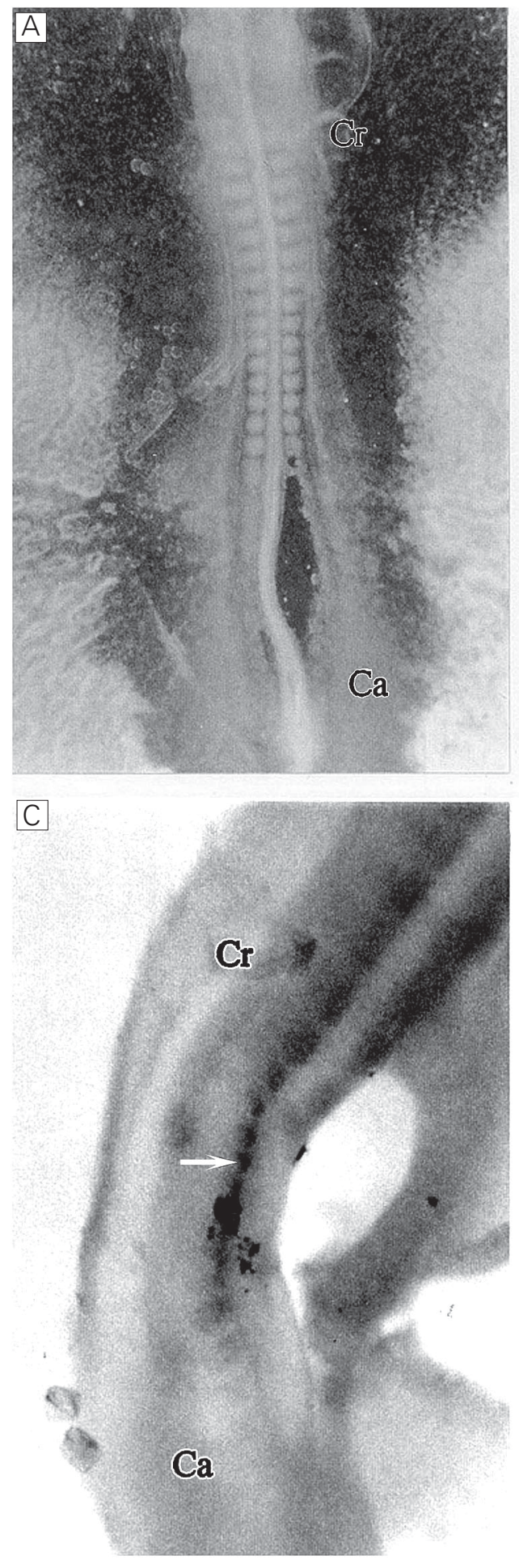

interesting to note that, as previously reported by Dietrich et al. (8), somites did form on the operated side, suggesting that axial structures do not interfere with the segmen-
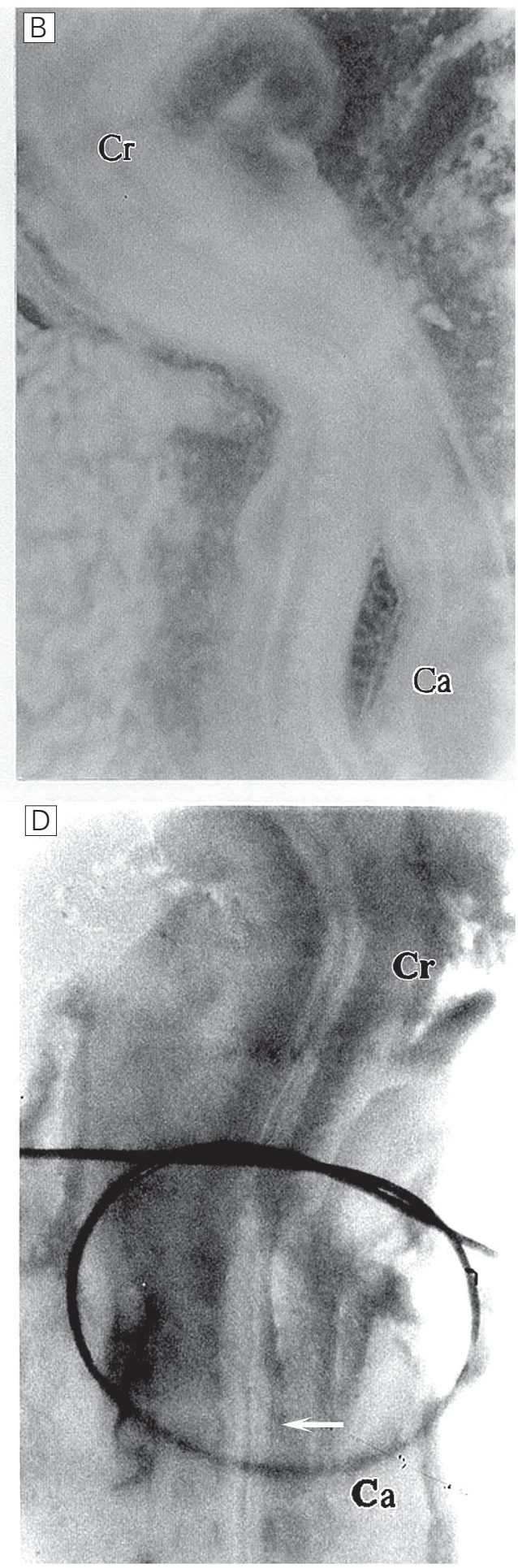
tation process of paraxial mesoderm into single somites (Figure 2B).

The $M y o D$ expression pattern in operated embryos is shown in Figure 2C, revealing that $M y o D$ transcripts were absent in somites separated from the axial structures (right side) while control somites were clearly labeled by the $M y o D$ probe, particularly in the region adjacent to the neural tube. Similarly, the myogenic factor qmf1 (MyoD analogue) was absent in somites separated from the NT/NC complex in quail embryos (18). Thus, our results strongly corroborate this and previous studies $(8,10,11,19)$, which showed that signals coming from the NT/NC complex influence activation of $M y o D$ expression and consequently somite differentiation. However, our data do not support the observations of Bober et al. (20), who suggested that $\mathrm{NT} / \mathrm{NC}$ are required to maintain but not to initiate $M y o D$ expression.

\section{Reapproximation of somites to NT/NC}

To confirm the role of NT/NC in $M y o D$ activation, we determined whether reapproximation of the axial structures would allow the myogenic process to continue in somites. For this purpose, needles with nylon thread were used to reapproximate somites to NT/ NC. Twelve to sixteen hours after reapproximation, myogenic factor $M y o D$ was expressed in somites that had been formerly separated, as shown in Figure 2D. These results reinforce the importance of NT/NC signaling to initiate $M y o D$ expression.

This ability of somitic cells to activate the myogenic program in response to signaling molecules emanating from NT/NC was previously described by Münsterberg and Lassar (9). These investigators conducted in vitro studies in which the three most caudal somites were cultivated in the absence or presence of the neural tube/basal plate/notochord complex. When somites were cultivated in the absence of axial structures, no MyoD, Myf-5, myogenin or myosin tran- scripts were detected. On the other hand, when somites from the contralateral side of the same embryo were cultivated in the presence of axial structures, both myogenic factors and myosin were expressed. Similar results were observed in vivo by Pownall et al. (18) in quail embryos.

\section{Competitive RT-PCR analysis of $M y o D$ expression}

Since in situ hybridization assays are not quantitative, it was not possible to compare the expression levels of $M y o D$ between the operated and control sides of embryos. Thus, we employed competitive RT-PCR to measure $M y o D$ transcripts in dissected somites. B-Actin expression was also quantified in order to control for variations in the quantity of RNA and the efficiency of cDNA synthesis. As summarized in Table 1, MyoD expression was almost undetectable in somites on the separated side, while on the contralateral side (control) the expression level was roughly 20 times higher. Quantification of MyoD mRNAs confirmed the results of in situ hybridization assays and the role of NT/ $\mathrm{NC}$ signals in induction of myogenesis.

Interestingly, somites on the operated side contained 1.5 times less $\beta$-actin mRNAs than

Table 1. Quantification of $M y O D$ and $B$-actin transcripts in separated and control somites of chicken embryos.

\begin{tabular}{lccc}
\hline Embryos & $\begin{array}{c}\text { MyoD } \\
\left(10^{-3} \text { attomol }\right)\end{array}$ & $\begin{array}{c}\text { B-Actin } \\
(1 \text { attomol })\end{array}$ & $\begin{array}{c}\text { Corrected } \mathrm{MyoD} \\
\left(10^{-3} / 1 \text { attomol }\right)\end{array}$ \\
\hline Control side & & & \\
1 & 0.22 & 0.34 & 0.65 \\
2 & 0.65 & 0.42 & 1.55 \\
3 & 0.92 & 0.95 & 0.96 \\
Average & 0.60 & 0.57 & 1.06 \\
Separated side & & & \\
1 & 0.00 & 0.06 & 0.00 \\
2 & 0.08 & 0.45 & 0.17 \\
3 & 0.00 & 0.59 & $0.066^{*}$ \\
Average & 0.03 & 0.37 & \\
\hline Each group contained 3 embryos. & & \\
${ }^{*}$ P<0.01 compared to control side (paired t-test). &
\end{tabular}




\begin{tabular}{|c|c|c|}
\hline Embryos & Control somites & Separated somites \\
\hline 1 & 30 & 22 \\
\hline 2 & 33 & 13 \\
\hline 3 & 18 & 19 \\
\hline Average & 27 & 18 \\
\hline
\end{tabular}
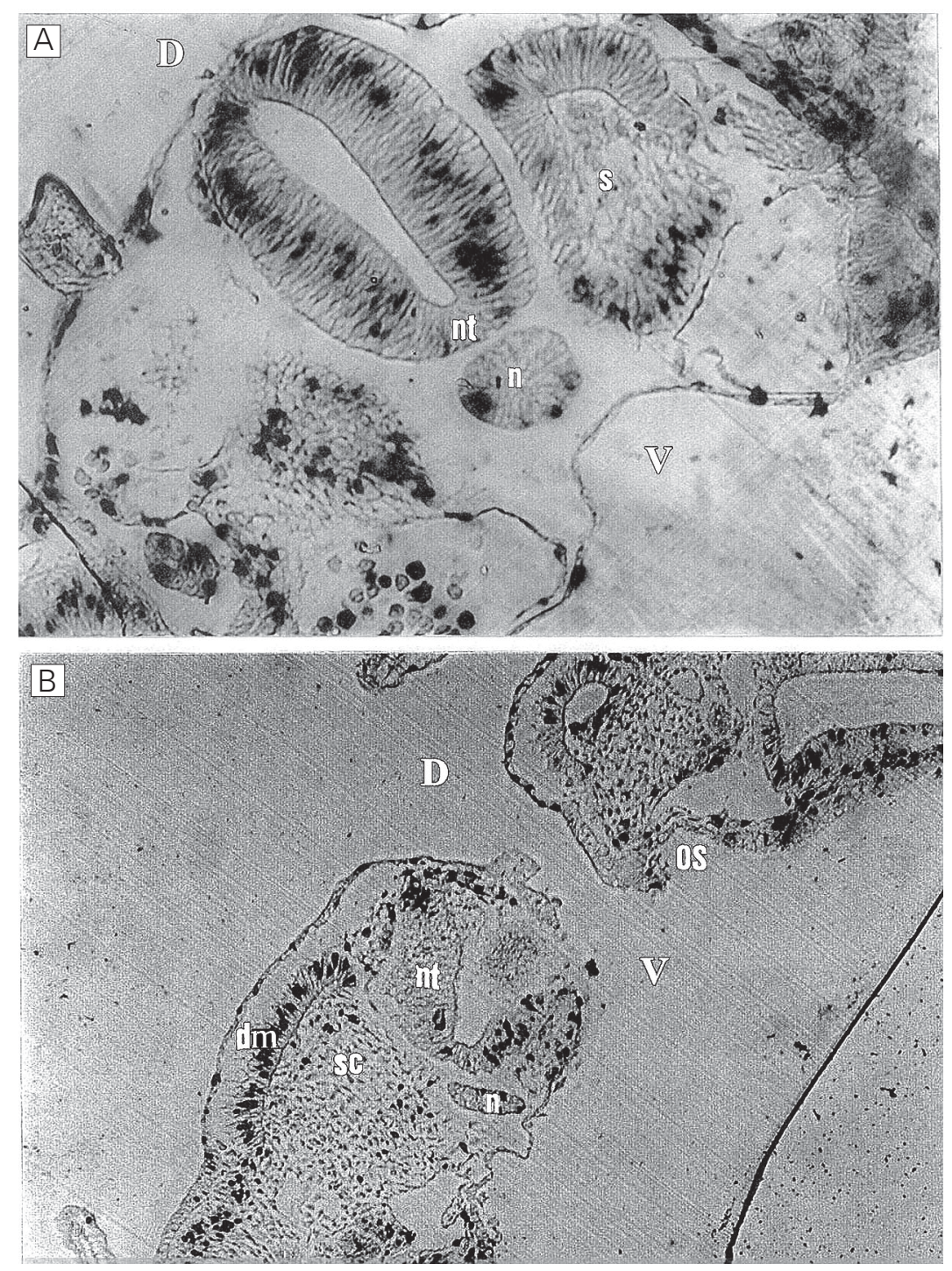

Figure 3. Cell proliferation in chicken embryos. $A$, Transverse section of an $\mathrm{HH} 12$ chicken embryo. $B$, Transverse section of a chicken embryo submitted to microsurgery. $\mathrm{nt}=$ neural tube, $\mathrm{n}=$ notochord, $\mathrm{s}=$ somite, $\mathrm{dm}=$ dermomyotome, $\mathrm{sc}=$ sclerotome, $\mathrm{OS}=$ operated side, $\mathrm{D}=$ dorsal region, $\mathrm{V}=$ ventral region. the control side $(\mathrm{P}<0.01)$. A possible explanation for this reduction is that trophic factors coming from the neural tube were absent on the operated side. These factors are believed to regulate the proliferative activity of myogenic precursor cells $(20,21)$.

\section{Cellular proliferation in operated embryos}

Expression of myogenic factors has been negatively associated with progression of the cell cycle (22). Our results show that separation of somites from axial structures prevents $M y o D$ expression and consequently could lead to a higher proliferative rate. To test this hypothesis, a thymidine analogue, BrdU, was used to label proliferating embryo cells.

Figure 3A shows a transverse section of an HH12 unoperated embryo. Proliferating cells of the neural tube, notochord and somites (in the initial phase of compartmentalization) can be observed. Cells that incorporate BrdU were identified by the formation of a dark signal in the nucleus. Proliferating cells in the neural tube were centrally ordered, which confirmed previous observations (16). Figure 3B shows a section of an operated embryo. Since operated embryos were older than unoperated embryos, somites were more mature and displayed an advanced compartmentalization process. As can be observed, the dermomyotome presents more intense proliferation activity than the sclerotome. Also, it is possible to note that somites on the separated side were smaller, less differentiated and irregularly shaped (Figure 3B).

The number of nuclei stained with BrdU in separated and control somites is presented in Table 2. These results revealed that there was a reduction, but not significant $(\mathrm{P}=$ 0.27 , paired $t$-test) in the number of proliferating cells on the separated side compared to the control side. Thus, under our experimental conditions, we did not confirm that a lack of $M y o D$ expression resulted in an increase 
in the rate of cellular proliferation in somites.

The present results show that the NT/NC complex induces $M y o D$ expression. How- ever, in the absence of $M y o D$, we did not observe a higher proliferation rate of muscle precursor cells that could result in an increased number of muscle lineage cells.

\section{References}

1. Ludolph DC \& Konieczny S (1995). Transcription factor families: muscling in on the myogenic program. FASEB Journal, 9: 15951604.

2. Stockdale FE, Nikovits Jr W \& Christ B (2000). Molecular and cellular biology of avian somite development. Developmental Dynamics, 219: 304-321.

3. Arnold HH \& Braun $\mathrm{T}$ (2000). Genetics of muscle determination and development. Current Topics in Developmental Biology, 48: 129164.

4. Davis RL, Weintraub $H$ \& Lassar AB (1987). Expression of a single transfected cDNA converts fibroblasts to myoblasts. Cell, 51: 9871000.

5. Braun $T$, Buschhausen-Denker G, Bober $E$, Tannich E \& Arnold $H H$ (1989). A novel human muscle factor related to but distinct from MyoD1 induces myogenic conversion in 10T1/2 fibroblasts. EMBO Journal, 8: 701-709.

6. Wright W, Sassoon DA \& Lin VK (1989). Myogenin, a factor regulating myogenesis, has a domain homologous to MyoD1. Cell, 56: 607617.

7. Rhodes S \& Konieczny SF (1989). Identification of MRF4: a new member of the muscle regulatory factor gene family. Genes and Development, 3: 2050-2061.

8. Dietrich S, Schubert FR, Healy C, Sharpe PT \& Lumsden A (1998). Specification of the hypaxial musculature. Development, 125: 22352249.

9. Münsterberg AE \& Lassar $A B$ (1995). Combinatorial signals from neural tube, floor plate and notochord induce myogenic bHLH gene expression in the somite. Development, 121: 651-660.

10. Buffinger N \& Stockdale FE (1994). Myogenic specification in somites: induction by axial structures. Development, 120: 14431452.

11. Pourquié O, Coltey M, Teillet MA, Ordahl C \& Le Douarin NM (1993). Control of dorsoventral patterning of somitic derivatives by notochord and floor plate. Proceedings of the National Academy of Sciences, USA, 90: 5242-5246.

12. Coutinho LL, Morris J, Marks HL, Buhr JR \& Ivarie R (1993). Delayed somite formation in a quail line exhibiting myofiber hyperplasia is accompanied by delayed expression of myogenic regulatory factors and myosin heavy chain. Development, 117: 563-569.

13. Hamburger $V$ \& Hamilton $H L$ (1951). A series of normal stages in the development of the chick embryo. Journal of Morphology, 88: 4992.

14. Coutinho LL, Morris J \& Ivarie R (1992). Whole mount in situ detection of low abundance transcripts of the myogenic factor qmf1 and myosin heavy chain protein in quail embryos. Biotechniques, 13: 722-724.

15. Gabriel JE, Alves HJ, Alvares LE, Schmidt GS \& Coutinho LL (2000). In situ detection of transcripts of the myogenic factor MyoD in whole chicken embryos. Genetics and Molecular Biology, 23: 145148.

16. Lopes ML, Schmidt GS \& Coutinho LL (2000). Identification of proliferating cells in chicken embryos through 5-bromo-2'-deoxyuridine immunohistochemical detection. Genetics and Molecular Biology, 23: 149-153.

17. Chomczynski P \& Sacchi N (1987). Single step method of RNA isolation by acid guanidinium thiocyanate-phenol-chloroform extraction. Analytical Biochemistry, 162: 156-159.

18. Pownall ME, Strunk KE \& Emerson CP (1996). Notochord signals control the transcriptional cascade of myogenic bHLH genes in somites of quail embryos. Development, 122: 1475-1488.

19. Goulding M, Lumsden A \& Paquette AJ (1994). Regulation of Pax-3 expression in the dermomyotome and its role in muscle development. Development, 120: 957-971.

20. Bober E, Brand-Saberi B, Ebensperger C, Wilting J, Balling R, Paterson BM, Arnold H-H \& Christ B (1994). Initial steps of myogenesis in somites are independent of influence from axial structures. Development, 120: 3073-3082.

21. Pourquié O, Coltey M, Breant C \& Le Douarin NM (1995). Control of somite patterning by signals from the lateral plate. Proceedings of the National Academy of Sciences, USA, 92: 3219-3223.

22. Puri PL \& Sartorelli V (2000). Regulation of muscle regulatory factors by DNA-binding, interacting proteins, and post-transcriptional modifications. Journal of Cellular Physiology, 185: 155-173. 